\title{
Die Wiskundige Verhoudingsbegrip in die Tydperk voor Euclides
}

DIE OU EGIPTENARE: Die volke wat hulle voor die Griekse tydperk met wiskunde besig gehou het, het hulle nie veel aan algemeengeldige begrippe gesteur nie. Hulle het weliswaar oor 'n groot hoeveelheid kennis omtrent ruimtelike en numeriese betrekkings en verhoudings beskik, maar die naspeuring en vasstelling van eenderse elemente in die natuurlike verskeidenheid het hulle links laat lê. Logiese afieidinge en bewyse het ook nie aandag geniet nie. 
Die groot hoeveelheid kennis wat die ou Egiptenare opgegaer het, was hoofsaaklik die vrug van empiriese ondersoek, of hoogstens veralgemenings wat gevolg het op onvolledige induksie van eenvoudige na meer ingewikkelde gevalle. Die Egiptiese reël hoe om die inhoud van ' $n$ piramide met 'n vierkantige basis te bereken, waarvandaan die opsienbarendste van alle Egiptiese resultate verkry is: die reël hoe om die inhoud van die frustum van 'n vierkantige piramide te bepaal, was waarskynlik die resultaat van hierdie berekeningsvorm. (Onder die frustum verstaan ons die deel van 'n piramide wat oorbly nadat die boonste deel afgesny is).

Van nog groter belang is die feit dat die Egiptenare hulle kennis alleen op konkrete gevalle met bepaalde getalle toegepas het. In hulle meetkunde kom ons die begrip driehoek wat alle driehoeke verteenwoordig, nie teë nie. Tot hierdie abstrakte veralgemening, noodsaaklik vir die uitwerking van 'n deduktiewe stelsel, het hulle nie gekom nie. Hierdie gebrek aan vryheid en verbeeldingskrag blyk ook uit die Egiptiese rekenkunde, waarin die abstrakte getalbegrip as sodanig nie voorgekom het nie, en waarin met die uitsondering van $2 / 3$, alle rasionale breuke as die som van stambreuke uitgedruk is. Die Egiptenare het byvoorbeeld $3 / 5$ nie as 'n enkele getal beskou nie, maar as die som van twee breuke: $\frac{1}{2}$ en $1 / 10$.

DIE BABILONIERS: In Babilonië is die numeriese meer benadruk as in Egipte; gevolglik is algebra verder ontwikkel, maar ook hier vind ons geen logiese struktuur of bewys nie. Daar word net met konkrete gevalle gehandel; ingewikkelder gevalle word hoogstens na eenvoudiger herlei.

DIE PYTHAGOREERS: Die begin van abstraksie: Dit is baie moeilik om te bepaal hoe die Egiptiese en Babiloniese wiskunde en die Griekse histories by mekaar aansluit. Dit is duidelik dat wiskunde 'n heeltemal nuwe aard gekry het, toe dit deur die Grieke verder ontwikkel is. Verhaal word dat die Griek Thales baie gereis het, en meetkunde by die Egiptenare en sterrekunde by die Babiloniërs geleer het. Met sy terugkoms in Griekeland het hy sy leerlinge in die geheimenisse ingelei; naas die empiriese behandeling het hy ook tot veralgemening oorgegaan. Thales was die vader van wiskunde as 'n deduktiewe dissipline.

Pythagoras het die meetkunde-studie in 'n liberale onderwys omgevorm; die beginsels van hierdie wetenskap het hy ondersoek, en die 
stellings op 'n intellektuele vlak nagevors. Watter deel van die werk Pythagoras self gedoen het en watter deel vir die rekening van sy' skool, die Pythagoreërs, moet kom, kan vandag moeilik onderskei word. Tog weet ons dat dié skool die proses van abstraksie wat deur Thales aangevoer is, voltooi het.

Die volgende stap in die Griekse gedagtegang was om die Pythagoreiese wiskundige begrippe weer op die natuur toe te pas. Meetkunde is beskou as immanent in die natuur; hulle het gemeen dat die geidealiseerde meetkundige begrippe in die stoflike wêreld gerealiseer is. Hierdie verwarring van die abstrakte met die konkrete, van rasionele begripsvorming met empiriese beskrywing, was karakteriserend van die hele Pythagoreiese skool. Sommige het dit as mistisisme bestempel.

DIE METING VAN OPPERVLAKKE: 'n Baie belangrike resultaat van die Pythagoreiese pogings om eenheid tussen natuur en meetkunde te vind, was hulle oppervlakteberekening. Griekse wiskundiges het nie van die oppervlakte van 'n figuur gespreek nie, maar van die verhouding van twee vlakke. Hierdie definisie kon nie afgerond word voordat 'n bevredigende getalbegrip ontwikkel is nie. Oor 'n sodanige begrip het die Pythagoreërs nie beskik nie.

DIE LENGTE VAN 'N LYN: Die Pythagoreërs het in hulle ontleding van die verhouding van groothede 'n baie onrusbarende ontdekking belewe. Wanneer die sy van 'n vierkant met die diagonaal vergelyk word, kan die lengte van die een nie in die ander uitgedruk word nie, m.a.w. die twee lyne is onderling onmeetbares. Volgens die Pythagoreërs het die eerste man wat hierdie ontdekking openbaar het, in 'n skipbreuk omgekom. Daarmee wou hulle te kenne gee dat al die irrasionele in die heelal onuitspreeklik en vormloos moes bly; wanneer 'n siel op 'n sodanige vorm afkom en dit openbaar, word hy binnegetrek in die oseaan van die wording en deur die rustelose strome daarvan omspoel.

Die onderlinge onmeetbaarheid van lyne het altyd vir die Griekse meetkunde 'n struikelblok gebly. Dit het nooit tot die Grieke deurgedring om 'n irrasionale getal te ontwerp om die moeilikheid te omseil nie, ofskoon hulle as ' $n$ deel van hul meetkunde 'n teorie van onmeetbare groothede ontwikkel het. Aangesien hulle nie daarin geslaag het om die getalbegrip uit te brei nie, moes die Grieke op die ou end maar afsien van die Pythagoreiese poging om die getalgebied te identifiseer met dié van die meetkunde of kontinue grootheid. 
HIPPOKRATES: Daar bestaan 'n wiskundige verhandeling van Hippokrates van Chios wat waarskynlik geskrywe is tydens sy verblyf te Athene gedurende die tweede helfte van die vyfde eeu voor Christus. 'n Ou legende verhaal dat die bewoners van die eiland Delos van Apollo die opdrag ontvang het om sy altaar met behoud van vorm te verdubbel. Daar is eers gemeen dat dit kan geskied deur die verdubbeling van die afmetinge. Dit was natuurlik 'n foutiewe oplossing vir die probleem om die inhoud van 'n kubus te verdubbel. Hippokrates was die eerste om in te sien dat die oplossing verkry kan word deur tussen twee lynstukke waarvan die een die dubbele van die ander is, twee middeewerediges in gedurige verhouding in te skakel.

PLATO: In Athene was die groot filosoof Plato, of skoon nie in die eerste plek wiskundige nie, tog in noue aanraking met die meetkundiges, en het baie in hulle probleme belang gestel. Hy was besonder geinteresseerd in die hipoteses, definisies en metode. Die Pythagoreïese probleem, die aard van die getal en sy verhouding tot meetkunde, die onderlinge onmeetbaarheid, ens., het sy aandag geniet. In hulle poging om die kloof tussen rekenkunde en meetkunde te oorbrug het die Platoniste probeer om die begrip van ondeelbaarhede of vaste infinitesimale te ontwikkel. Oor rekenkunde het Plato in "Die Staat" geskrywe: „Wanneer dit beoefen word in die gees van die filosoof en nie van 'n winkelier nie, het rekenkunde 'n baie groot en verheffende invloed wat die siel dwing om te redeneer oor die abstrakte getal, en rebelleer teen die invoering van sigbare of tasbare voorwerpe in die redenering."

Nog altyd het die Grieke onder die las gebuk gegaan dat hulle geen duidelike getalbegrip gehad het nie, maar nog so gebonde was aan die konkrete dat 'n getal vir hulle die verhouding van twee lynstukke of twee oppervlaktes was. Die veronagsaming van die abstrakte idealiserings wat Plato voorgestel het, maar nooit duidelik gedefinieer het nie, was moontlik ook tot 'n mate te wyte aan die teenkanting van die induktiewe wetenskaplike gesigspunte van Aristoteles en die Peripatetiese skool.

EUDOXOS: Ons het tans genader tot een van die grootste wetenskaplike figure van die Griekse Oudheid, die wiskundige en astronoom Eudoxos (408-355 voor Christus). Oor sy lewe word verhaal dat hy voor sy 25e jaar te Athene onder die gehoor van Plato vertoef het, dat hy daarna in Egipte was en vervolgens in Kuzikos 'n groot skool om hom versamel het, waarmee hy hom in 368 in Athene gevestig het. 
Ofskoon Plato nie die probleme van die Pythagoreërs kon oplos nie, het hy sy metgeselle aangemoedig om met hierdie studie voort te gaan. In sy boek "Nomoi" het hy in krasse bewoordinge gekla oor die ,meer vark- as menswaardige toestand", dat alle Hellene verkeer ,in 'n belaglike en skandelike onwetendheid ten aansien van die meting van dit wat lengte, breedte en diepte het." As eerste algemeen-verspreide dwaling is genoem dat alle Hellene meen dat alle lengtes onderling en alle verhoudings onderling steeds meetbaar is.

Verhaal word dat Plato aan Eudoxos 'n aantal probleme in stereometrie wat die infinetesimaalrekening suggereer, voorgestel het.

Aan Eudoxos het ons die „uitputtingsmetode” te danke. In sy uitputtingsmetode toegepas op oppervlaktes en inhoude, het Eudoxos aangetoon dat ons nie nodig het om die bestaan van oneindig klein hoeveelhede te veronderstel nie. Vir die doeleindes van die wiskunde is dit voldoende as ons 'n hoeveelheid willekeurig klein deur die volgehoue verdeling van 'n gegewe hoeveelheid, kan bereik.

Eudoxos staan ook bekend vir sy epogmakende definisie van gelyke verhoudings wat wiskundiges in staat gestel het om irrasionale getalle net so goed te hanteer as rasionale getalle. Dit was die beginpunt van ons moderne irrasionale getalleteorie: „Die eerste van vier groothede staan in dieselfde verhouding tot die tweede as die derde tot die vierde wanneer enige gelyke veelvoude van die eerste en die tweede geneem word, en enige ander gelyke veelvoud van die derde en die vierde, en die veelvoud van die eerste groter, kleiner of gelyk is aan die veelvoud van die tweede, netsoos die veelvoud van die derde groter, kleiner of gelyk is aan die veelvoud van die vierde".

Die ontdekking van die onderlinge onmeetbaarheid van lynstukke en oppervlagtes, die moontlikheid dat die verhouding tussen gelyksoortige nie as getalle uitgedruk kan word nie, het 'n sterk invloed op die ontwikkeling van die Griekse wiskunde uitgeoefen. Daarom het die verhoudingsteorie van Eudoxos 'n groot bydrae gelewer tot die oorwinning oor die "scandale logique" wat deur hierdie ontdekking veroorsaak is. Ons sê inderdaad nie te veel nie wanneer ons hierdie teorie, 'n eersterangse geestesskepping, tot die indrukwekkendste monumente van die Griekse kultuur reken. Die prestasie van Eudoxos was dié van 'n wiskundige wat ook 'n natuurwetenskaplike was, sonder enigiets geheimsinnigs of misties.

Ontdekkers.

A. J. VAN ROOY. 